\title{
Systemic Hyperthermia Induces Ischemic Brain Injury in Neonatal Mice With Ligated Carotid Artery and Jugular Vein
}

\author{
SIARHEI SLINKO, CASPER CASPERSEN, VENIAMIN RATNER, JIN-JI KIM, PAUL ALEXANDROV, RICHARD POLIN, \\ AND VADIM S. TEN
}

Department of Pediatrics, Division of Neonatology, Columbia University, New York, New York 10032

\begin{abstract}
Postnatal d 7 (p7) or p12 mice had their right carotid artery (CA) and jugular vein (JV) ligated to mimic veno-arterial (VA) access for extracorporeal membrane oxygenation (ECMO). At p9-11 (early) or p19-21 (late) mice were exposed to hyperthermia or normothermia followed by assessment of neuropathological injury score. In separate cohorts of mice, cerebral and peripheral blood flow $(\mathrm{CBF}, \mathrm{PBF})$ and cerebral ATP content was measured. Hyperthermia resulted in ischemic brain injury in $57 \%$ and $77 \%$ of mice subjected to early or late hyperthermia, respectively. Isolated CA+JV ligation induced minimal injury (score $0.47 \pm 0.34$ ) in $2 / 8$ mice from the late normothermia group. No cerebral injury was detected in mice subjected to early normothermia. In 3/19 shams (2/10 early, 1/9 late) hyperthermia induced a subtle (score, $0.6 \pm 0.27$ ) injury in the ipsilateral to the site of surgery cortex. $\mathrm{CBF}$ and PBF increased in response to hyperthermia in all mice. The rise in CBF was significantly attenuated in the "ligated" versus intact hemisphere, which was associated with a profound depletion of ATP content. Systemic hyperthermia induces ischemic brain injury in mice with ligated $\mathrm{CA}+\mathrm{JV}$. We speculate that hyperthermia/fever can be a potential risk factor for brain injury in infants treated with VA ECMO. (Pediatr Res 62: 65-70, 2007)
\end{abstract}

$\mathrm{T}$ There is ongoing concern that permanent ligation of the CA following VA ECMO-treatment may adversely affect cerebral perfusion. An analysis of ECMO complications in 7667 neonates demonstrated that, in comparison with VA ECMO, VV ECMO was associated with a significantly lower mortality rate and incidence of major neurologic complications, including cerebral infarction (1). Although the use of VV ECMO has increased from $14 \%$ in $1990-1999$ (2) to $24.7 \%$ in 2001-2004 (3), the VA ECMO remains the preferred mode. In ECMOtreated neonates, CA-ligation, but not JV-ligation, resulted in a significant decrease in oxyhemoglobin concentration (and rise in the deoxyhemoglobin level) in the brain (4). The incidence of cerebral ischemic lesions associated with lateralized neuromotor dysfunction and abnormal electroencephalography is significantly increased in the side ipsilateral to VA ECMO cannulation (5-7). Reconstruction of CA following VA ECMO results in a long-term patency of the CA in $76-93 \%$ of patients and may decrease the incidence of brainscan abnormalities and cerebral palsy $(8,9)$. However, the lack

Received August 30, 2006; accepted February 12, 2007.

Correspondence: Vadim S. Ten, M.D., Ph.D., Division of Neonatology, Department of Pediatrics, Columbia University, 3959 Broadway CHN 1201, New York, NY 10032; e-mail: vt82@columbia.edu

This study was partially supported by the American Heart Association, grant SDG0635077N (V.T.). of data on direct causality of CA-ligation in cerebral complications of VA ECMO makes the rationale for routine reconstruction of CA controversial.

Experimental studies showed that in healthy newborn lambs an isolated CA ligation did not significantly alter CBF and oxygen metabolism (10). In rats, CA-ligation induced a longterm vascular adaptation with improvement of collateral circulation between the ligated and nonligated hemispheres (11). However, it is unknown whether the collateral circulation is sufficient to meet increased cerebral metabolic demands. It is well established that systemic hyperthermia (fever) significantly increases cerebral metabolic demand and is associated with a steep increase in CBF $(12,13)$. Given that permanent loss of the $\mathrm{CA}+\mathrm{JV}$ can potentially limit the rise in $\mathrm{CBF}$ in response to metabolic demand, we hypothesized that systemic hyperthermia/fever may induce cerebral ischemia in a hemisphere that has undergone $\mathrm{CA}+\mathrm{JV}$ ligation.

\section{MATERIALS AND METHODS}

Three-day-old, C57/BL6J mice of both genders were purchased from Jackson Laboratories (Bar Harbor, ME) with their birth mothers. All research was conducted according to a protocol approved by the Columbia University Animal Care and Use Committee.

The procedure and study-groups. At $\mathrm{p} 7$, under isoflurane anesthesia, experimental mice had their right $\mathrm{CA}+\mathrm{JV}$ permanently ligated using 10-0 polypropylene. To induce anesthesia, mice were placed for $20 \mathrm{~s}$ into a plastic, 100-mL-volume chamber containing an isoflurane-saturated cotton-tip. Anesthesia was maintained for 5-7 min by holding the same cotton-tip near the animal's nose. In sham-operated mice, the CA $+\mathrm{JV}$ were exposed, but not ligated. At $2 \mathrm{~d}$ after surgery, CA+JV-ligated and sham-mice were divided into two subgroups: Hyperthermia and Normothermia. Hyperthermic mice were exposed to ambient temperature of $38.5^{\circ} \mathrm{C}$ in a chamber partially submerged in a water bath. To achieve an even exposure to the ambient temperature, mice were placed into plastic-net hammock installed $2 \mathrm{~cm}$ above the bottom of the chamber. During hyperthermic exposure, the chamber was constantly flushed with humidified air at $1.5 \mathrm{~L} / \mathrm{min}$. Normothermic exposure was produced by placing mice into isolette (Air-shields, Respironics, Murrysville, PA ) preheated to $32^{\circ} \mathrm{C}$, the average temperature in the mouse nest (14). Each mouse was exposed to hyperthermia or normothermia for $10 \mathrm{~min}$, twice a day for three consecutive days. Hyperthermic exposure was produced at p9-11 (early hyperthermia). Rodents at this age are widely used to model infantile febrile seizures (15).

An additional cohort of p12 mice was subjected to the same experimental protocol with the only difference that the hyperthermic stress was delayed to p19-21 (late hyperthermia). At p12, the development of mouse brain corresponds to that in full-term infant (16). The time of hyperthermic stress was

Abbreviations: $\mathbf{C A}+\mathbf{J V}$, carotid artery and jugular vein; $\mathbf{C B F}$, cerebral blood flow; PBF, peripheral blood flow; p7, postnatal d 7; +t, hyperthermia; -t, normothermia; VA ECMO, veno-arterial extracorporeal membrane oxygenation; VV ECMO, veno-venous extracorporeal membrane oxygenation 
delayed to a weanling age because at this age mice become independent on dam's nursing which is comparable to 12-24-mo-old infants, the age when the incidence of febrile complications is the highest (17).

As the main goal of this study was to determine whether an isolated ligation of CA + JV followed by hyperthermia induces cerebral ischemia, mice were not subjected to hypoxia, which other investigators have used to model preECMO hypoxemia in rodents (18).

A total of 90 mice were analyzed and the following groups were studied: $\mathrm{CA}+\mathrm{JV}+$ hyperthermia (43 mice), $\mathrm{CA}+\mathrm{JV}+$ normothermia (18 mice), shamoperated+hyperthermia (19 mice), and sham-operated+normothermia (10 mice). Each litter consisted of sham-operated and CA+JV-ligated mice subjected to either hyperthermia or normothermia. Two mice from the $\mathrm{CV}+\mathrm{JV}+$ hyperthermia group that died before the neuropathological exam were excluded. Mice that were cannibalized before hyperthermia exposure were not studied.

Neurofunctional assessment. Neurofunctional assessment was performed only in mice subjected to CA+JV ligation at $\mathrm{p} 7$. At $5 \mathrm{~d}$ following ligation (24 $\mathrm{h}$ after the last hyperthermia episode), neonatal sensorimotor mouse reflex (geotaxis and cliff aversion) performance was tested and compared between groups. The protocol for reflex performance assessment has been previously described by our group (19). For the geotaxis reflex, mice were placed on inclined $\left(40^{\circ}\right)$ foam-made and claw-friendly board. Time (seconds) that each mouse took to turn its body $>90^{\circ}$ head-up was recorded. For the cliff-aversion reflex, mice were placed with overhanging paws at the edge of the clawfriendly, 20-cm-high board. The time (seconds) that a mouse took to crawl away from the edge was recorded. Each mouse was given three attempts to perform a reflex with $2 \mathrm{~min}$ of rest between trials. If a mouse was unable to perform the reflex, $20 \mathrm{~s}$ of the allotted time was assigned to this animal. Mean value of the time spent in all three attempts was used for data analysis. Following an assessment of reflex performance, mice were decapitated under deep isoflurane anesthesia and brains were removed and fixed in $4 \%$ paraformaldehyde. Because neonatal murine reflexes disappear with the age, mice subjected to hyperthermia in the weanling age were not tested.

Neuropathological assessment. Forty-micron coronal sections were cut on a vibrating microtome and Nissl-stained. For neuropathological analysis, three consecutive sections from anterior, mid, and posterior levels in relation to bregma $(-1.2 \mathrm{~mm}$-anterior, $-2 \mathrm{~mm}$ - mid, and $-2.5 \mathrm{~mm}$-posterior $)$ were analyzed. The neuropathological evaluation of injury was done using a neuropathological score described by Sheldon et al. (20). The score was analyzed in three regions of the cortex (anterior, mid, and posterior), four regions of the hippocampus (CA1, CA2, CA3, DG), and one region of the mid-thalamus. Analysis was performed in a blinded fashion. Regions were scored: grade $0=$ no evidence of injury; grade $1=$ rare scattered pyknotic, hyperchromic cells; grade 2 = single or small confluent areas of necrosis, grade $3=$ large, multiple areas of necrosis more then $50 \%$ of the tissue loss thalamus or hippocampus, or/and areas of cystic infarction in the cortex. Grades from each of the three cortical regions, mid-thalamus and four hippocampal regions were summated.

Measurements of rectal temperature, cerebral and peripheral blood flows. Two separate cohorts of mice were used to measure $\mathrm{CBF}$ and PBF. In the first cohort, the real-time changes in $\mathrm{CBF}$ and $\mathrm{PBF}$ were recorded before and immediately following CA $+\mathrm{JV}$ ligation, and for $80 \mathrm{~min}$ following surgery (including a single episode of hyperthermia). This cohort of mice was used to study changes in PBF and in CBF in relation to the preligation level.

In the second cohort of $\mathrm{p} 9$ mice, the rectal temperature, $\mathrm{CBF}$, and $\mathrm{PBF}$ were recorded during hyperthermic or normothermic exposure at $48 \mathrm{~h}$ after sham- or ligation surgeries. Rectal temperature was measured in randomly selected mice using a 1-mm-diameter rectal probe (Cole-Parmer, Vernon Hills, IL) attached to the thermometer (Termalert TH-5, Physitemp, Clifton, $\mathrm{NJ})$. CBF was measured using a three-channel laser-Doppler flowmeter "Periflux 5000," as described earlier $(21,22)$. Briefly, under isoflurane, anesthesia following small scalp incision two laser-Doppler probes were attached to the skull using $15-\mathrm{cm}-$ long fiberoptic extensions. To minimize a "crosstalk" between hemispheres in CBF recording, fiberoptic extensions were placed parallel to each other, $2.5-3 \mathrm{~mm}$ lateral to and $2 \mathrm{~cm}$ posterior to the bregma. The wound was closed using tissue glue followed by an injection of local anesthetic. PBF was recorded by the placement of the laser Dopplerprobe on supine surface of the hind paw. CBF and PBF changes were recorded continuously and expressed as a percentage of the preligation value in cohort 1 and as a percentage of the prehyperthermia level in cohort 2. In cohort 1, changes in $\mathrm{CBF}$ and $\mathrm{PBF}$ were analyzed every 5 min following ligation and every $2 \mathrm{~min}$ during exposure to hyperthermia. In cohort 2, changes in $\mathrm{CBF}$ and $\mathrm{PBF}$ were analyzed every 2 min during exposure to normothermia or hyperthermia.

The measurement of cerebral ATP content. To study changes in cerebral metabolism, the ATP content was measured in both hemispheres at the end of a single episode of normothermia or hyperthermia (cohort 2). ATP content was determined using a Bioluminescence Assay CLS II (Roche Molecular Biochemicals, Indianapolis, IN). Briefly, at the end of exposure, brains were harvested and snap-frozen in the liquid nitrogen. Forty seconds were spent to harvest the brain from each mouse. On the same or the next day, ipsilateral and contralateral hemispheres were homogenized and kept in boiling, 100 $\mathrm{mM}$ Tris, $4 \mathrm{mM}$ EDTA (pH 7.75) for $2 \mathrm{~min}$. An aliquot was obtained for determination of protein concentration using the Bio-Rad protein assay (Bio-Rad, Hercules, CA) with BSA as a standard. The homogenate was centrifuged at $15,000 \mathrm{~g}$ for $5 \mathrm{~min}$. ATP was measured in supernatant using black multiwell plates and SPECTRAFluor Plus Tecan luminometer (Tecan, Mannedorf, Switzerland). The ATP concentration was expressed in micromoles per gram of tissue protein.

Statistical analysis. One-way ANOVA and Bonferroni's posthoc analyses were used for comparative assessment of the extent of cerebral injury, neurofunctional performance, cerebral ATP content, and summated values of CBF and $\mathrm{PBF}$ changes between groups. To compare changes in rectal temperature, $\mathrm{CBF}$ and PBF with the baseline the ANOVA for repeated measures was used. Data were considered statistically significant if $p<0.05$ between groups.

\section{RESULTS}

As expected, the exposure to $38.5^{\circ} \mathrm{C}$ for $10 \mathrm{~min}$ significantly $(p<0.0001)$ increased rectal temperature in both $\mathrm{CA}+\mathrm{JV}$-ligated $\left(39.8 \pm 1.2^{\circ} \mathrm{C} n=9\right)$ and sham-operated mice $\left(39.7 \pm 1.3^{\circ} \mathrm{C} n=6\right)$ compared with the baseline $\left(29.4 \pm 2.2^{\circ} \mathrm{C}\right.$ and $29.3 \pm 1.02^{\circ} \mathrm{C}$, respectively). When $\mathrm{CA}+\mathrm{JV}$-ligated and sham-operated mice were exposed to normothermia, their rectal temperature increased (35.3 \pm $0.87^{\circ} \mathrm{C}$ and $34.3 \pm 0.4^{\circ} \mathrm{C}$, respectively, $n=5$ ), but significantly $(p<0.0001)$ less than in hyperthermic counterparts.

The ligation of the $\mathrm{CA}+\mathrm{JV}$ resulted in a significant decrease in $\mathrm{CBF}$ in the ipsilateral (ligated) hemisphere that remained significantly less then the preligation level for 40 min of recording (Fig. 1, $A$ and $B$ ). No changes in CBF were

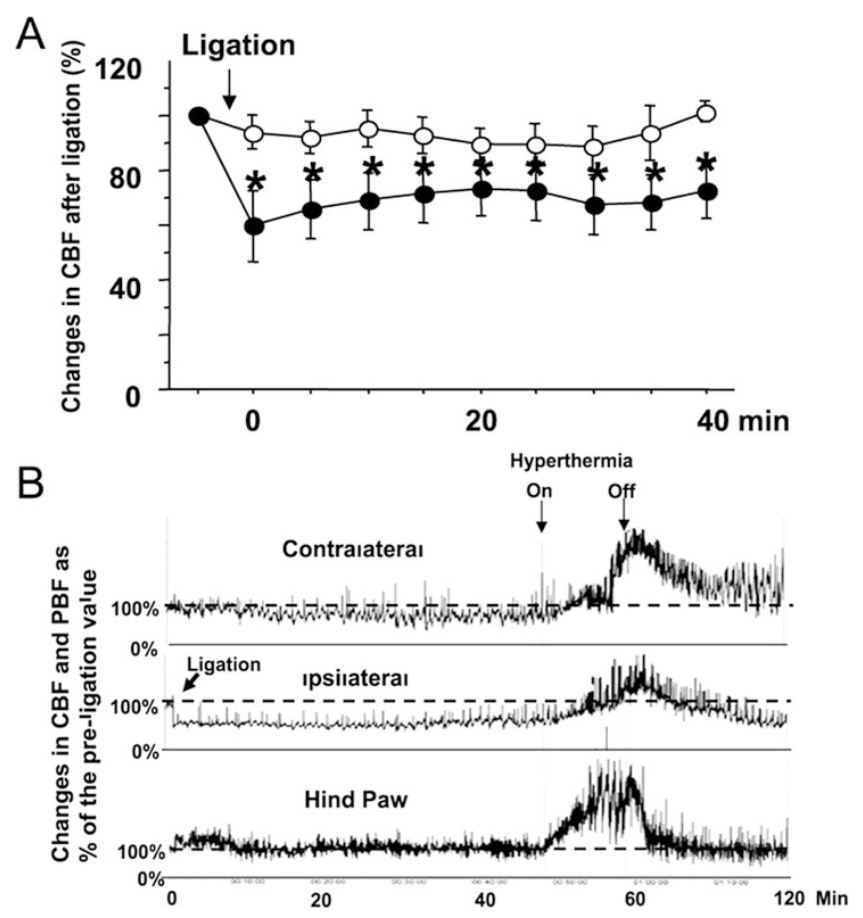

Figure 1. (A) Changes in the CBF in "ligated" (black circles) and "nonligated" (open circles) hemispheres during and after ligation of CA $+\mathrm{JV}(n=$ 4). Data are mean \pm SE. $* p<0.0002$ compared with the preligation value. $(B)$ The real-time changes in $\mathrm{CBF}$ and $\mathrm{PBF}$ in a single mouse during ligation of the CA $+\mathrm{JV}$ followed by the hyperthermic exposure. The arrow indicates the moment of ligation and the beginning and the end of hyperthermia. The blood flow changes are percentage of the preligation value. 


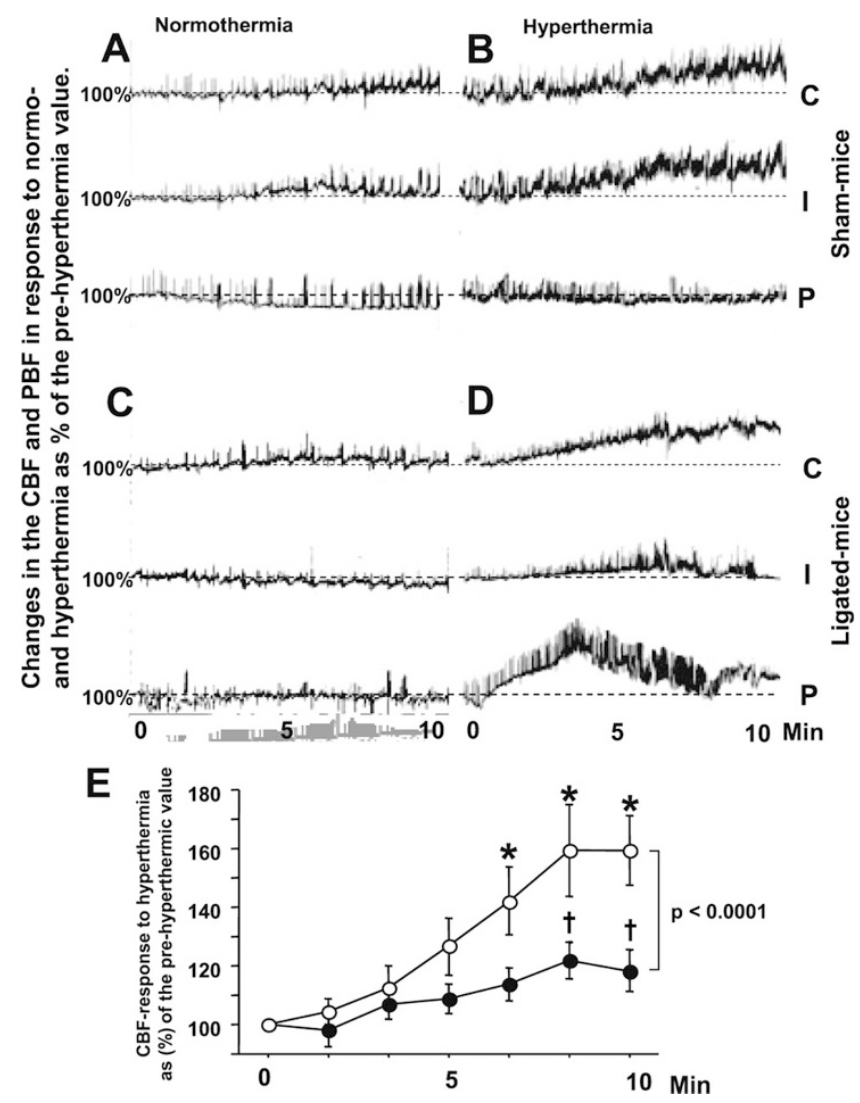

Figure 2. The real-time changes in $\mathrm{CBF}$ and PBF during normo- and hyperthermia in sham + normothermia $(A)$, sham +hyperthermia $(B)$, $\mathrm{CA}+\mathrm{JV}+$ normothermia $(C)$, and $\mathrm{CA}+\mathrm{JV}+$ hyperthermia $(D) \mathrm{p} 9$ mice. All data are expressed as percentage of the preexposure values and measured in $\mathrm{C}$ [contralateral (nonligated)] and I [ipsilateral (ligated) hemispheres], and $\mathrm{P}$ (hind paw). (E) The mean values of the CBF changes in the "ligated" (black circles) and "nonligated" (open circles) hemispheres during hyperthermia in $\mathrm{CA}+\mathrm{JV}$-ligated mice $(n=10)$. CBF changes are percentage of the prehyperthermia values. $p$ Values for comparison of CBF-changes between hemispheres are indicated. ${ }^{*} p<0.003$ and $\dagger p<0.01$ compared with the prehyperthermia level.

observed in the contralateral, "nonligated" hemisphere during ligation (Fig. 1, $A$ and $B$ ). In mice with $\mathrm{CA}+\mathrm{JV}$-ligation, the hyperthermic stress resulted in a significant increase in $\mathrm{CBF}$ and $\mathrm{PBF}$ compared with the preligation and prehyperthermia levels (Fig. 1B, Fig. 2, $D$ and $E$ ). The increase in CBF in response to hyperthermia was significantly greater in the "nonligated" hemisphere compared with that in the "ligated" hemisphere (Fig. 1B, Fig. 2, $D$ and $E$ ). Compared with that in sham-operated mice, the same degree of hyperthermia caused a significantly greater increase in $\mathrm{PBF}(p<0.0001)$ and CBF $(p=0.004)$ in the "nonligated" hemisphere in CA + JV-ligated mice (Fig. 2, $B$ and $D$, and Fig. 3, $B$ and $C$ ). In contrast, the hyperthermia-induced rise in CBF in the "ligated" hemisphere was significantly less compared with that in the sham-operated counterparts (Fig. 2, $B$ and $D$, and Fig. 3A). Exposure to a normothermic environment had no effect on PBF or CBF in the contralateral hemisphere in either $\mathrm{CA}+\mathrm{JV}$-ligated or sham-operated mice (Fig. 2, $A$ and $C$, and Fig. 3, $B$ and $C$ ). However, the CBF in the "ligated" hemisphere decreased slightly (by 20\%) during the normothermic exposure and

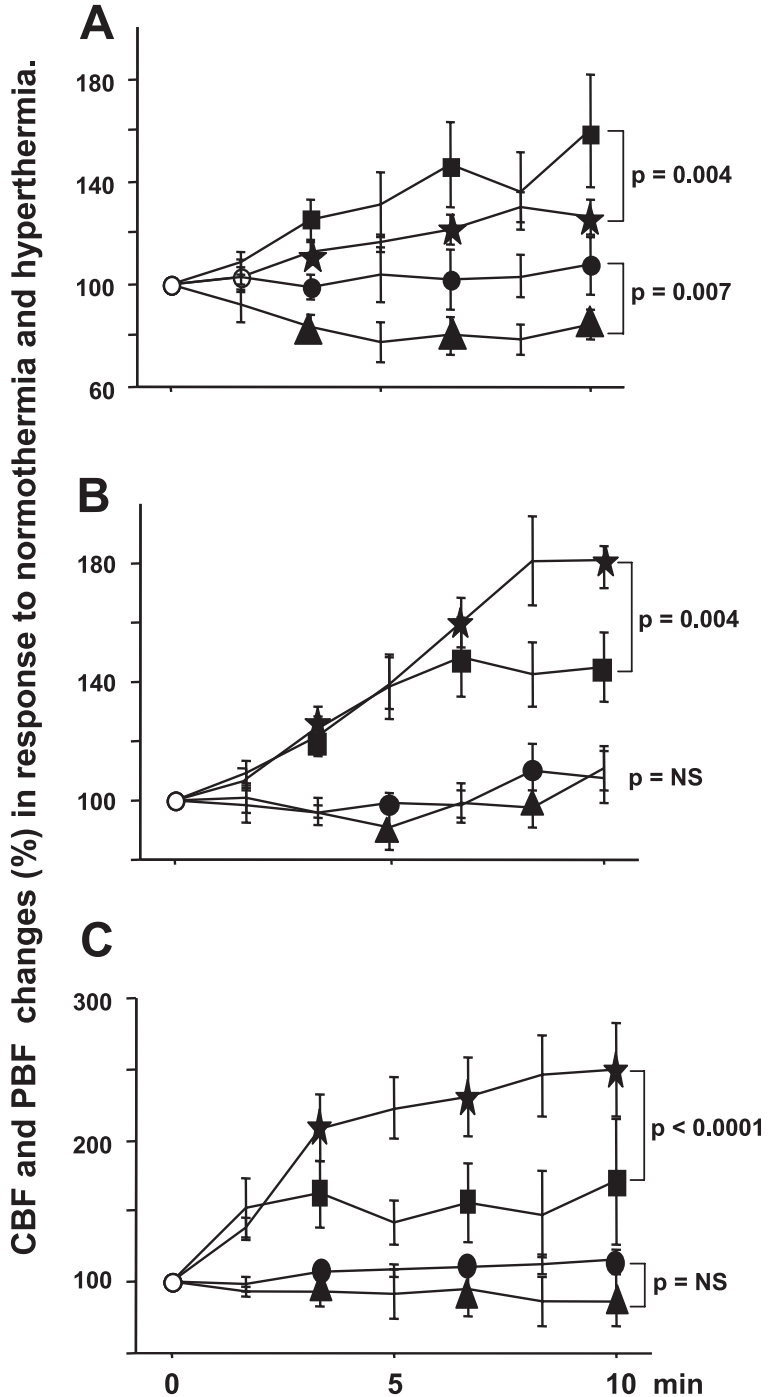

Figure 3. Blood flow changes in the ipsilateral $(A)$ and contralateral $(B)$ hemispheres and in the hind paw $(C)$ in $\mathrm{p} 9$ mice during normothermic or hyperthermic exposure. Star, CA $+\mathrm{JV}+\mathrm{t}(n=10)$; triangle, CA $+\mathrm{JV}-\mathrm{t}$ $(n=9)$; square, Sham $+\mathrm{t}(n=7)$; circle, Sham-t $(n=4)$. Data expressed as mean $\pm \mathrm{SE}(\%)$ of preexposure values.

remained significantly $(p=0.007)$ lower compared with that in sham-operated normothermic counterparts (Fig. 3A).

The combination of CA+JV ligation with a superimposed hyperthermic stress resulted in a profound (3.5-fold) decrease in the cerebral ATP content compared with that in normothermic mice (Fig. 4A). Ligation of CA+JV and exposure of these mice to normothermic environment also caused a significant $(p=0.0057)$ decrease in the ATP content in the ipsilateral hemisphere compared with the same hemisphere in sham-mice, but not when compared with that in the contralateral hemisphere. There was no difference in ATP content in sham-normothermic compared with sham-hyperthermic mice (Fig. 4A).

Neuropathological exam revealed that isolated CA+JVligation without hyperthermic stress induced cerebral damage in 2/18 mice (Fig. 4F). Both of these mice had their CA+JV ligated at p12 and exposed to normothermia at their weanling age. In contrast, 26 out of $41 \mathrm{CA}+\mathrm{JV}$-ligated animals experiencing early (16/28) or delayed (10/13) hyperthermic stress 
A

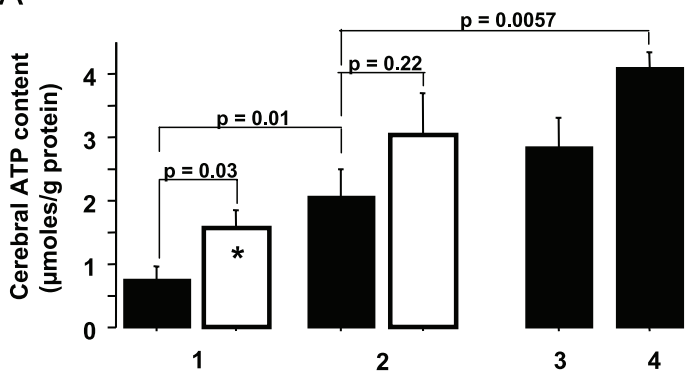

B

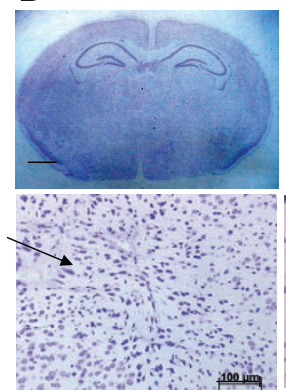

$\mathrm{E}$
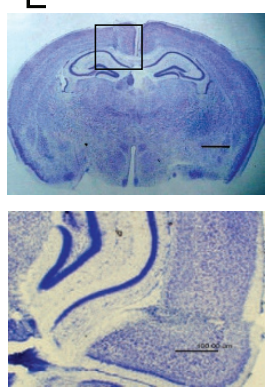

C

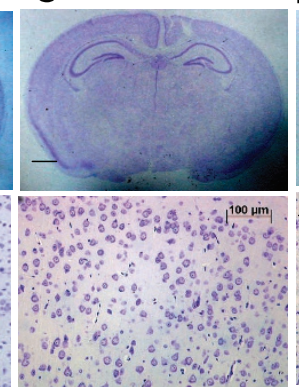

$\mathrm{F}$
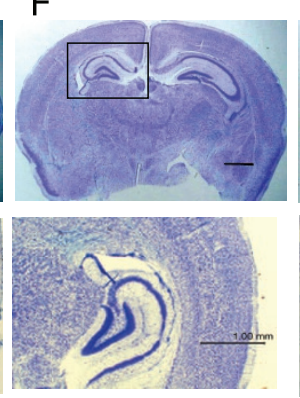

D

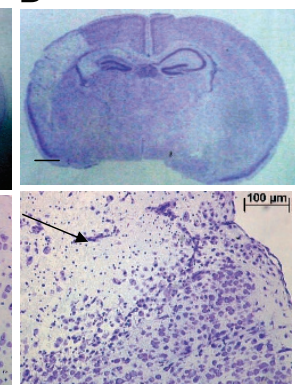

G
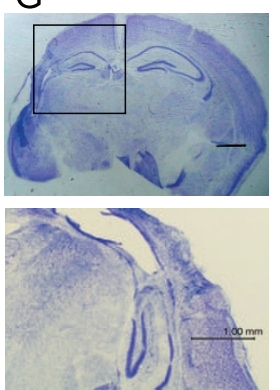

Figure 4. (A) Cerebral ATP-content in the ipsilateral (black bars) and contralateral (white bars) hemispheres at the end of normothermic or hyperthermic exposure in $\mathrm{p} 9$ mice; 1$) \mathrm{CA}+\mathrm{JV}+\mathrm{t}(n=9), 2) \mathrm{CA}+\mathrm{JV}-\mathrm{t}(n=9), 3)$ $\mathrm{Sham}+\mathrm{t}(n=7)$, and 4) Sham-t $(n=4)$. Data are mean $\pm \mathrm{SE} * p=0.035$ compared with the $\mathrm{CA}+\mathrm{JV}+$ normothermia mice. $(B-G)$ Nissl-stained coronal sections of brain from mice subjected to early, p9-11 $(B-D)$ and late, p19-21 $(E-G)$ hyperthermia $(B, E)$ Sham $+\mathrm{t},(C, F) \mathrm{CA}+\mathrm{JV}-\mathrm{t}$, and $(D, G)$ $\mathrm{CA}+\mathrm{JV}+\mathrm{t}$ mice. Scale bars $=2 \mathrm{~mm}, 1 \mathrm{~mm}, 100 \mu \mathrm{m}$.

developed an infarct in the hemisphere ipsilateral to the ligation side (Fig. 4, $D$ and $G$, and Fig. 5, $A$ and $B$ ). Unexpectedly, in 3 ( 2 from early and 1 from late hyperthermia groups) out of 19 sham-operated mice the neuropathological exam revealed small areas of cerebral necrosis (hyperchromia, cellular shrinkage) in the hemisphere ipsilateral to the surgical site (Fig. 4, $B$ and $E$ ). The neuropathological score in CA+JVhyperthermic mice was significantly higher which was asso- ciated with a significantly more sluggish reflex performance compared with that in their normothermic counterparts and sham-hyperthermic mice (Fig. 5, $A-D$ ).

\section{DISCUSSION}

This study demonstrates that, in neonatal mice, permanent $\mathrm{CA}+\mathrm{JV}$ ligation followed by delayed repetitive short-term systemic hyperthermia can produce an ischemic cerebral injury in the hemisphere ipsilateral to the ligation side. The ischemic nature of this damage is supported by a significant reduction of the $\mathrm{CBF}$ following $\mathrm{CA}+\mathrm{JV}$ ligation and a profound depletion of the ATP content during superimposed hyperthermic stress. These animal data raise a critical question: Is fever/hyperthermia a potential risk factor for cerebral injury in infants following VA ECMO?

Clinical data suggest that infants treated with VA ECMO exhibit a significantly higher rate of seizures and cerebral infarcts compared with VV ECMO-treated counterparts (2). Experimental data showed that in healthy newborn lambs VA ECMO, but not VV ECMO altered cerebral autoregulation and significantly decreased CBF in the hemisphere ipsilateral to the cannulation side (23). In our experiments, mice with $\mathrm{CA}+\mathrm{JV}$ ligation exhibited a significant (by $50 \%$ ) and prolonged (40 min) reduction of CBF in the "ligated" hemisphere. In contrast, Hunter et al. (24) using an ECMO-model in neonatal lambs reported only a transient $(60 \mathrm{~s})$ drop in CBF following ipsilateral CA + JV ligation. Short and co-workers (25) also reported that CA+JV ligation in neonatal lambs did not alter either CBF or the CBF-response to hypoxia. It is possible that $\mathrm{CBF}-$ response to $\mathrm{CA}+\mathrm{JV}$ ligation may be species-dependent. In baboons, ligation of the right carotid artery resulted in an immediate fall of the right ophthalmic artery pressure that was sustained for 2 wk (26). In human infants, the blood flow in the internal carotid artery was reduced by 74\% even at 4-9 y after ipsilateral CA ligation (27).

Lewin and co-authors (23) reported that $50 \%$ of neonates treated with VA ECMO exhibited an antegrade CBF in their right, ligated internal $\mathrm{CA}$ with blood velocities comparable to that in normal infants or in the contralateral side. Using magnetic resonance angiography, the same investigators demonstrated full patency of the right internal CA in 9 out of 16 infants at less then a week after VA ECMO (28). These data indicate that collateral blood flow develops shortly after VA ECMO has ended. Pearlman et al. (29) reported a symmetrical pattern of the CBF in both hemispheres in 1-y-old infants treated with VA ECMO as neonates. However, it is unknown
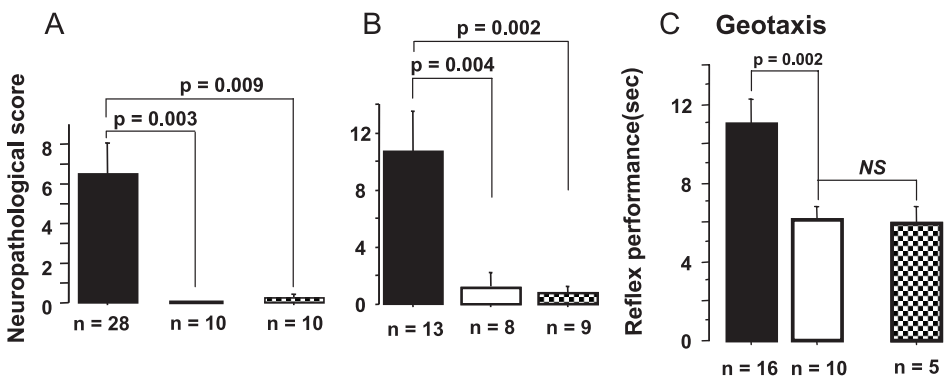

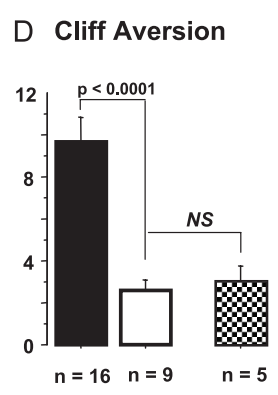

Figure 5. Neuropathological score in $\mathrm{CA}+\mathrm{JV}$ mice subjected to early $(A)$ and late $(B)$ hyperthermia. $(C)$ Geotaxis and (D) cliff-aversion reflex performance in mice subjected to early hyperthermia. $\mathrm{CA}+\mathrm{JV}+\mathrm{t}$ (black bar), CA $+\mathrm{JV}-\mathrm{t}$ (white bar), and sham $+\mathrm{t}$ (checkered bar) mice. Data are mean $\pm \mathrm{SE} \mathrm{n}$ and $p$ values are indicated. 
whether cerebral perfusion would have remained symmetrical if cerebral metabolic demand had increased. In this study, we demonstrated that ligation of CA $+\mathrm{JV}$ significantly attenuates the CBF-response to hyperthermia and was associated with development of cerebral infarct in the "ligated" hemisphere.

Systemic hyperthermia significantly increases cerebral metabolic rate in adult humans (23\%) (13), and in newborn pigs $(65 \%)(12)$. In parallel with the increase in cerebral metabolic rate, there is a sharp (by 97\%) rise in CBF in response to systemic hyperthermia in pigs (12). The hypermetabolic state during hyperthermia has been implicated in the pathogenesis of the heat stroke. Heat stroke is characterized by the development of cerebral ischemic injury following severe heat exposure $(30,31)$. The ambient temperature $\left(38.5^{\circ} \mathrm{C}\right)$ used in this study was significantly lower compared with that used in heat-stroke models in rats $\left(43^{\circ} \mathrm{C}\right)(32)$ and mice $\left(41.8^{\circ} \mathrm{C}\right)(33)$. Nevertheless, the CA+JV-ligated mice developed brain infarcts ipsilateral to the ligation side. This finding suggests that permanent $\mathrm{CA}+\mathrm{JV}$ ligation limits the CBF-response to hyperthermia, which may cause a mismatch between $\mathrm{O}_{2}$-demand and delivery. This statement is supported by the data showing a profound ATP depletion in the "ligated" hemisphere after hyperthermic stress. During heat stroke, the ATP content falls significantly in the ischemic brain in rodents (34).

The normothermic exposure induced a mild (scores 3 and 6, max score $=24$ ) cerebral injury in $2 / 18 \mathrm{CA}+\mathrm{JV}$-ligated mice. Both these mice were subjected to $32^{\circ} \mathrm{C}$ at their weanling age, the age when mice are not dependent on heat generated by dam or nesting. The ambient temperature of $32^{\circ} \mathrm{C}$ can be viewed as a relatively hot environment for these mice. It has been reported that isolated CA ligation resulted in an ischemic brain injury in $71 \%$ of p12 mice $(10,35)$. However, in this study authors used a mouse strain (CD-1) known to be highly susceptible to ischemic brain injury (36). Furthermore, these mice were exposed to $35^{\circ} \mathrm{C}$ for $4 \mathrm{~h}$ following ligation. In adult rats, CA $+\mathrm{JV}$ ligation combined with or without preceding hypoxia was shown to cause sporadic and occasional brain damage (18). In CA +JV-ligated mice subjected to normothermia at p9-11, no cerebral damage was detected. Although, rectal temperature in these mice increased significantly compared with the baseline, no significant changes in CBF, PBF, or ATP-content were recorded. The increase in rectal temperature during normothermic exposure in $\mathrm{p} 9$ mice can be viewed as a normalization of the temperature-balance following relative hypothermia induced by exposure to the room temperature of $25^{\circ} \mathrm{C}$ during handling and placement of the $\mathrm{CBF}, \mathrm{PBF}$, and rectal temperature-probes. In our study, the rectal temperature of $39^{\circ} \mathrm{C}$ was strongly associated with brain damage in mice with $\mathrm{CA}+\mathrm{JV}$ ligation. The incidence of cerebral injury increased from $57 \%$ in mice with ligation at $\mathrm{p} 7$ and hyperthermia at p9-11 to $77 \%$ in mice with delayed ligation and hyperthermia (p12 and p19-21). Of note, it has been reported that the incidence of abnormal neuro-outcome at 36 mo following ECMO-treatment of noncardiac respiratory failure was higher among pediatric ECMO (30\%) than among neonatal ECMO (8.3\%) patients (37).

Hyperthermia increased PBF and CBF (in the contralateral hemisphere) in $\mathrm{CA}+\mathrm{JV}$-ligated mice significantly greater compared with that in the sham-animals. It is possible that hyperthermia-induced hypermetabolism in the "ligated" (ischemic) hemisphere demanded an increase in systemic blood flow which resulted in relative hyperperfusion of the contralateral hemisphere and peripheral tissue. Lohrer and co-workers (38) have reported a significant increase in diastolic and mean $\mathrm{CBF}$ velocities in the internal CA contralateral to the cannulation side during and after ECMO compared with the preECMO level and compared with that in controls.

Three out of 19 sham-hyperthermic mice exhibited subtle, microscopically identifiable focal areas of cerebral damage. This finding was unexpected. Given that brain injury in these mice was observed in the cortex ipsilateral to the surgery site, it is possible that the postsurgical tissue edema altered CA and JV blood flow during hyperthermia, which resulted in brain damage.

In conclusion, our study has identified a hyperthermic stress as a potential risk factor for ischemic brain injury in infants treated with VA ECMO. Unilateral CA +JV ligation followed by hyperthermia exposure may serve as a modified heat-stroke model for immature rodents.

Acknowledgments. The authors thank Dr. C. Stolar for helpful suggestions during preparation of the manuscript.

\section{REFERENCES}

1. Zwischenberger JB, Nguyen TT, Upp JR Jr, Bush PE, Cox CS Jr, Delosh T, Broemling L 1994 Complications of neonatal extracorporeal membrane oxygenation. Collective experience from the Extracorporeal Life Support Organization. J Thorac Cardiovasc Surg 107:838-848 discussion 848-839

2. Dimmitt RA, Moss RL, Rhine WD, Benitz WE, Henry MC, Vanmeurs KP 2001 Venoarterial versus venovenous extracorporeal membrane oxygenation in congenital diaphragmatic hernia: the Extracorporeal Life Support Organization Registry, 19901999. J Pediatr Surg 36:1199-1204

3. Conrad SA, Rycus PT, Dalton H 2005 Extracorporeal Life Support Registry Report 2004. ASAIO J 51:4-10

4. Van Heijst A, Liem D, Hopman J, Van Der Staak F, Sengers R 2004 Oxygenation and hemodynamics in left and right cerebral hemispheres during induction of veno-arterial extracorporeal membrane oxygenation. J Pediatr 144:223-228

5. Schumacher RE, Barks JD, Johnston MV, Donn SM, Scher MS, Roloff DW, Bartlett RH 1988 Right-sided brain lesions in infants following extracorporeal membrane oxygenation. Pediatrics 82:155-161

6. Campbell LR, Bunyapen C, Holmes GL, Howell CG Jr, Kanto WP Jr 1988 Right common carotid artery ligation in extracorporeal membrane oxygenation. J Pediatr 113:110-113

7. Hahn JS, Vaucher Y, Bejar R, Coen RW 1993 Electroencephalographic and neuroimaging findings in neonates undergoing extracorporeal membrane oxygenation. Neuropediatrics 24:19-24

8. Desai SA, Stanley C, Gringlas M, Merton DA, Wolfson PJ, Needleman L, Graziani LJ, Baumgart S 1999 Five-year follow-up of neonates with reconstructed right common carotid arteries after extracorporeal membrane oxygenation. J Pediatr 134:428-433

9. Sarioglu A, McGahren ED, Rodgers BM 2000 Effects of carotid artery repair following neonatal extracorporeal membrane oxygenation. Pediatr Surg Int 16:15-18

10. Short BL, Walker LK, Gleason CA, Jones MD Jr, Traystman RJ 1990 Effect of extracorporeal membrane oxygenation on cerebral blood flow and cerebral oxygen metabolism in newborn sheep. Pediatr Res 28:50-53

11. Bronner G, Mitchell K, Welsh FA 1998 Cerebrovascular adaptation after unilateral carotid artery ligation in the rat: preservation of blood flow and ATP during forebrain ischemia. J Cereb Blood Flow Metab 18:118-121

12. Busija DW, Leffler CW, Pourcyrous M 1988 Hyperthermia increases cerebral metabolic rate and blood flow in neonatal pigs. Am J Physiol 255:H343-H346

13. Nunneley SA, Martin CC, Slauson JW, Hearon CM, Nickerson LD, Mason PA 2002 Changes in regional cerebral metabolism during systemic hyperthermia in humans. J Appl Physiol 92:846-851

14. Dirks A, Fish EW, Kikusui T, van der Gugten J, Groenink L, Olivier B, Miczek KA 2002 Effects of corticotropin-releasing hormone on distress vocalizations and locomotion in maternally separated mouse pups. Pharmacol Biochem Behav 72:993-999

15. Bender RA, Dube C, Baram TZ 2004 Febrile seizures and mechanisms of epileptogenesis: insights from an animal model. Adv Exp Med Biol 548:213-225

16. Romijn HJ, Hofman MA, Gramsbergen A 1991 At what age is the developing cerebral cortex of the rat comparable to that of the full-term newborn human baby? Early Hum Dev 26:61-67 
17. Millar JS 2006 Evaluation and treatment of the child with febrile seizure. Am Fam Physician 73:1761-1764

18. Klein MD, Lessin MS, Whittlesey GC, Chang CH, Becker CJ, Meyer SL, Smith AM 1997 Carotid artery and jugular vein ligation with and without hypoxia in the rat. J Pediatr Surg 32:565-570

19. Ten VS, Bradley-Moore M, Gingrich JA, Stark RI, Pinsky DJ 2003 Brain injury and neurofunctional deficit in neonatal mice with hypoxic-ischemic encephalopathy. Behav Brain Res 145:209-219

20. Sheldon RA, Jiang X, Francisco C, Christen S, Vexler ZS, Tauber MG, Ferriero DM 2004 Manipulation of antioxidant pathways in neonatal murine brain. Pediatr Res 56:656-662

21. Ten VS, Sosunov SA, Mazer SP, Stark RI, Caspersen C, Sughrue ME, Botto M, Connolly ES Jr, Pinsky DJ 2005 C1q-deficiency is neuroprotective against hypoxicischemic brain injury in neonatal mice. Stroke 36:2244-2250

22. Presti AL, Kishkurno SV, Slinko SK, Randis TM, Ratner VI, Polin RA, Ten VS 2006 Reoxygenation with $100 \%$ oxygen versus room air: late neuroanatomical and neurofunctional outcome in neonatal mice with hypoxic-ischemic brain injury. Pediatr Res 60:55-59

23. Walker LK, Short BL, Traystman RJ 1996 Impairment of cerebral autoregulation during venovenous extracorporeal membrane oxygenation in the newborn lamb. Crit Care Med 24:2001-2006

24. Hunter CJ, Blood AB, Bishai JM, Hickerson AD, Wall DD, Peverini RL, Power GG, Hopper AO 2004 Cerebral blood flow and oxygenation during venoarterial and venovenous extracorporeal membrane oxygenation in the newborn lamb. Pediatr Crit Care Med 5:475-481

25. Short BL, Bender K, Walker LK, Traystman RJ 1994 The cerebrovascular response to prolonged hypoxia with carotid artery and jugular vein ligation in the newborn lamb. J Pediatr Surg 29:887-891

26. Symon L, Russell RW 1971 The development of cerebral collateral circulation following occlusion of vessels in the neck. An experimental study in baboons. J Neurol Sci 13:197-208
27. Lott IT, McPherson D, Towne B, Johnson D, Starr A 1990 Long-term neurophysiologic outcome after neonatal extracorporeal membrane oxygenation. J Pediatr 116:343-349

28. Lewin JS, Masaryk TJ, Modic MT, Ross JS, Stork EK, Wiznitzer M 1989 Extracorporeal membrane oxygenation in infants: angiographic and parenchymal evaluation of the brain with MR imaging. Radiology 173:361-365

29. Perlman JM, Altman DI 1992 Symmetric cerebral blood flow in newborns who have undergone successful extracorporeal membrane oxygenation. Pediatrics 89:235-239

30. Chou YT, Lai ST, Lee CC, Lin MT 2003 Hypothermia attenuates circulatory shock and cerebral ischemia in experimental heatstroke. Shock 19:388-393

31. Yan YE, Zhao YQ, Wang H, Fan M 2006 Pathophysiological factors underlying heatstroke. Med Hypotheses 67:609-617

32. Chen SH, Chang FM, Niu KC, Lin MY, Lin MT 2006 Resuscitation from experimental heatstroke by estrogen therapy. Crit Care Med 34:1113-1118

33. Chatterjee S, Premachandran S, Sharma D, Bagewadikar RS, Poduval TB 2005 Therapeutic treatment with L-arginine rescues mice from heat stroke-induced death: physiological and molecular mechanisms. Shock 24:341-347

34. Wang JL, Ke DS, Lin MT 2005 Heat shock pretreatment may protect against heatstroke-induced circulatory shock and cerebral ischemia by reducing oxidative stress and energy depletion. Shock 23:161-167

35. Comi AM, Johnston MV, Wilson MA 2005 Immature mouse unilateral carotid ligation model of stroke. J Child Neurol 20:980-983

36. Sheldon RA, Sedik C, Ferriero DM 1998 Strain-related brain injury in neonatal mice subjected to hypoxia-ischemia. Brain Res 810:114-122

37. Amigoni A, Pettenazzo A, Biban P, Suppiej A, Freato F, Zaramella P, Zacchello F 2005 Neurologic outcome in children after extracorporeal membrane oxygenation: prognostic value of diagnostic tests. Pediatr Neurol 32:173-179

38. Lohrer RM, Bejar RF, Simko AJ, Moulton SL, Cornish JD 1992 Internal carotid artery blood flow velocities before, during, and after extracorporeal membrane oxygenation. Am J Dis Child 146:201-207 